\title{
N. 内分泌療法の進歩
}

\section{6. がんのホルモン療法}

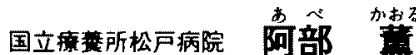

\section{はじめに}

がん細胞はいろいろな増殖因子によりその発育 が司どられている．増殖因子の代表の一つがホル モンであり，乳がんの場合には姓ホルモンであ る。そのため乳がんに扔いては，女性ホルモンの 作用をブロックする様な方法が治療に用いられ る．同じような機構が前立腺がんにおいても存在 しており，この場合には增殖因子である男性ホル モンの作用をブロックすることが治療に慗がる.

本日は私の専門とする乳がんのホルモン療法を 主体として述べ，加えて新しいホルモン療法が可 能になった膵内分泌腺腫瘍，前立腺がんについて も簡単にふれてみたい。

\section{1. 乳がん}

乳がんでホルモン療法の対象となるのは進行乳 がんである．進行乳がんとは，手術後に再発，転 移したもの，および初診時にすでに転移があり， 手術適応のないものである。なお本日は内科の会 であるため, 乳がん手術後の補助療法としての木 ルモン療法については述べない．

乳がんの増殖㟔女性ホルモンに依存しておう， そのため，女性ホルモンを除く（両側卵巣摘除， 両側副腎摘除，下垂体摘除)，または抗女性ホル モン作用を持った薬物（抗女性ホルモン薬，男性 ホルモン薬，女性ホルモン合成醏素阻害薬など） が治療に用いられている．内分泌腺を取り除く外 科的ホルモン療法は，抗女性ホルモン薬を始めと する内科的治療法の発達により最近はあまり行わ れなくなり，ことに両側副腎摘除，下垂体摘除は 内科的ホルモン療法に取って変わられている。

進行乳がんに対するホルモン療法は非常に有効 な手段ではあるが，すべての症例に効果があるわ けではなく，各ホルモン療法により多少の差はあ るとしても有効率は大体30\%程度である。
ホルモン療法が有効である症例を治療前にある 程度予測することは可能である。そそれは，乳がん の手術から再発するまでの期間の長いこと（時に は10年以上のこともある)，閉経後 5 年以上経過 していること，前に行われたホルモン療法が有効 であったような症例，転移部位が手術局所や皮下 のリンパ節が主なような症例などはホルモン療法 の有効性が高いことが予測される。ことにこの様 なホルモン療法の有効性の予測に重要なのはがん 組織中のエストロゲン受容体 (estrogen receptor, ER）の存在である.

多くの研究により，乳がん組織中の ER が 5 $\mathrm{fmol} / \mathrm{mg}$ protein 以上ある場合を ER 陽性，その他 を ER 陰性とすると，ER 陽性の場合にホルモン 療法の有効率は $65 \%$ 程度であるのに対し，ER 陰 性の場合の有効率は $10 \%$ 以下に過ざないことが明 らかにされている。そそのた，手術時，乳がん組 織中の ER の測定は重要であり，その結果はカル テに記載し，再発時の治療の参考に資するべきで あるＥR 測定のためには，がん組織を手術摘除 後直ちに凍結して保存することが必要である．手 術時に測定されていない場合には，転移巣が手術 した局所とか頝部リンパ節で，切除可能な場合に は摘除し，ERを測定することが望ましい。一般 に原発巣と転移巣との ERの成績はよく一致して おりこことにER 陰性の場合には一致率が高い. なお，ERの結果とホルモン療法の種類には特に 関係はなく，各患者の病態にあったホルモン療法 を選択することになるが，その問題については以 下の各論において述べる。

\section{1）抗女性ホルモン薬}

抗女性ホルモン薬として最も広く用いられてい るのは tamoxifen (TAM, Nolvadex) である。そ の作用機序はエストロゲンの ER に対する結合を 
競合的に阻害することで作用を発揮する．しかし 最近の研究によると直接的に蛋白合成を阻害する 作用もあるといわれている，経口薬で 1 日投与量 は20 mg, 朝夕に分服する. 副作用は極めて軽微で, まれに顔面の灼熱感, 血小板減少が認められるこ とがあるが，臨床的にはまず問題にならない。他 のホルモン療法と比較しても副作用が少ないこと から, 現在, 第一選択のホルモン療法薬として用い られている。進行乳がん全体に対する有効率は $30 \%$ 前後で, ER 陽性の場合には60\%程度と報告 されている.しかし，肝転移や脳転移病巣などに 対する有効率は一般に低く，この様な場合には後 述するように多剤による抗がん薬治療の方がよ い.

TAM 治療で治療開始後に比較的早期に認めら れる tamoxifen flare という現象がある。これは 転移病巣の発赤, 腫脹, 骨転移病巣の疼痛, 高力 ルシウム血症などで副作用と考えられがちであ る.しかし TAM 投与によりこの様な病態が生じ た場合には，TAM 治療の有効性を示唆しており， 対症的に治療すれば TAMの投与を必ずしも中止 する必要はない。

\section{2) Medroxyprogesterone acetate(MPA)}

黄体ホルモン薬であるが，大量投与が必要であ $り$ ，最近 1 錠 $200 \mathrm{mg}$ を含む MPA 錠 (Hysron-H) が市販されている．経口薬で 1 日600〜1,200 mg を 3 回に分服する．全体的な有効率はほほTAM と同程度であり，同じく ER 陽性例に対する有効 率が高い。また一般的に軟部組織，骨の病巣に対 して有効率が高く，肝転移，脳転移などに対して は有効率が落ちることも TAM と同じである．副 作用としては，体重増加，ムーンフェイス，性器 出血, 浮腫, 糖尿病の悪化, 口渴などがある.こ

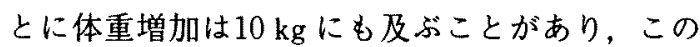
様な場合には節食が必要である。しかし，この様 に食欲を促進させ体重増加を来すような作用は， がん患者,ことに抗がん薬治療中の患者には有利 な面でもあり，臨床的にこの薬物を使用する重要 なポイントにもなる.

TAMに比較するとホルモン作用に由来する副 作用が強いため、ホルモン治療薬としては first choice として使用せず，前に行ったホルモン治療 が有効であった症例などを対象として投与したほ うがよい. 最近, 副作用として血栓症が報告され ている.これは投与量, 患者の病態などとは関係 なく発症して来る. 販売元の調査でその頻度は $0.1 \%$ 程度とのことであるが, 死亡例も報告され ているため, 前に行ったホルモン療法の結果, ERの成績などを勘案し，十分に効果が期待でき るような症例に絞り投与すべきであろう.

\section{3) Fluoxymesterone (Halotestin)}

男性ホルモン薬で, MPA と同じように, TAM が有効であったが治療を続けている間に病が進行 し，無効となったような症例がよい対称となる. また，TAM が無効でも，ER 陽性もしくは不明 の場合には投与を試みてもよい。一般に骨転移に は有効性が高い，経口薬で 1 日の投与量は $20 \mathrm{mg} 、$ 朝夕に分服する。副作用としては男性化が認めら れ，顔は脂ぎり，にきびが多発し，ひげも生え， 声も太くなる。この様な状態は投与する前に患者 に十分に説明しておく必要がある．時には細胆管 性の肝炎を起こすことがあるが，この場合には投 与を中止するべきである。

\section{4) Aminoglutethimide (AG)}

AG (Orimetin) は以前に抗けいれん薬として 用いられていたが，投与された患者が時に副腎皮 質不全を起こすことが注目され, Cushing 症候群 の患者の治療に用いられるようになった。そして 最近では進行乳がん患者の治療にまで適応が広が っている. 作用は cholesterol から pregnenolone への変換の抑制と, 肝, 脂肪組織などに扔いて, 男性ホルモン系統のステロイドを女性ホルモンに 変換する䤉素である aromatase の抑制である.

経口薬で，使用法ははじめ 2 週間は 1 日500 $\mathrm{mg}$ （2 錠）を朝夕に分服，それ以後は $1,000 \mathrm{mg}$ 1 日 4 回に分け投与する。それと共にコーチゾー ル (hydrocortisone) $40 \mathrm{mg}$ を朝夕に分服投与する. これは予測されている副腎皮質不全を防ぐためで ある。

報告されている有効率は，ER 陽性の場合には $53 \%$ ，ER 不明の場合には $35 \%$ というような数字 が報告されている．以前から両側卵巣摘除が有効 
であった症例が再燃した場合には，両側副腎摘除 の有効率の高いことが知られており， $\mathrm{AG}$ を用い れば medical adrenalectomy が可能であり，実際 的にはこの様な使い方が注目されている. 本邦で はまだ販売されていない。

\section{5）ホルモン富法か化学裳法か}

進行乳がんに関しては，抗がん剮療法による化 学療法もかなり有効である. doxorubicin (adriamycin), cyclophosphamide, methotrexate, 5-fluorourail 等多くの抗がん薬が20 40\%程度有効であ り，しかも抗がん薬を多剂併用すればその有効性 がさらに増すことが明らかにされている。すると 実際に治療を始める時に，各患者にホルモン療法 で行くべきか，それとも多剤併用の化学療法で治 療したほうがよいかがまず問題になる。一般的に 言って, ERがマイナス, 特に progesterone receptorもマイナスというような症例はホルモン療 法が有効である可能性が非常に低いので化学療法 の方がよい．また，転移が広範であり，ことに多 発性の肝転移, リンパ行性の肺転移を持つような 症例も化学療法が第一選択となる．前にホルモン 療法の有効性が高い症例の特徽について述べた が,これと反対のことが化学療法の適応症例につ いてはあげられると思う。

しかし，この様な一般論のみでホルモン療法を 選ぶか, 化学療法にするかの選択は決して容易で はない，原則的には上記の様な症例を除いては， まず副作用の少ないホルモン療法を行い，無効の 時には化学療法に移行する initial endocrine therapyというのが治療の原則的アプローチである. ホルモン療法が有効で，治療を続けている間に無 効となった様な症例には，他の種類のホルモン療 法が有効である可能性が高いので，種類の異なる ホルモン療法が選択される.

ホルモン療法が有効であり, 多唷併用化学療法 も十分な有効性が期待できるので，初めからこの 両者を同時に投与するホルモン・化学療法 (chemo - endocrine therapy）の方がより有効性が高いの ではないかということで比較検討が行われてい る。まだ最終的な結論は得られていないが，閉経 後ではTAMをまず投与し，無効な場合には化学
療法に移行するという方針がほぼ明らかにされて いる．しかし，閉経前の患者については，ホルモ ン・化学療法により, 腫瘍縮小効果は高くなるが 生存率は向上しないという結果も報告されてお り, 今後さらに詳細な検討が必要である。しかし, 広範な内臓転移があり，最初の治療がうまく行か なければ症状の改善は得られず, 死に至る様な症 例については，多剤併用の化学療法にホルモン療 法を加之，可能な限りの治療を行ってもよいと思 j.

進行乳がんに対し，現在可能な治療により治療 を得るということはまず不可能である。しかし， ホルモン療法, 多片化学療法が有効であれば, 症 状の改善, 疼痛の消失などによる quality of life の向上，そして延命が得られる，各症例について その適応と限界を明確にとらえ, 適切な治療を行 うことが非常に重要と考えられる。

\section{2. 膵内分泌腫㴼 (pancreatic endocrine tumors)}

膵のランゲルハンス島 (ラ島) からは種々のホル モンを分泌する腫瘍が発生する。これが膵内分泌 腫演であり，その代表的なものに insulinoma, gastrin を分泌する gastrinoma (Zollinger-Ellison (ZE) 症候群) vasoactive initestinal polypeptide (VIP) を 合泌する VIPoma (WDHA 症候群)，glucagonを分 泌する glucagonoma などがある。

これらの疾患の治療の基本は外科的摘除であ る.しかしインスリノーマを除き，多くが悪性で 発見時に肝などに転移していることが多く、また， 難治性の消化性潰瘍，水样性下痢などにより病態 も悪化している場合が決してまれでない。この様 な症例に対してはソマトスタチンの誘導体が内科 的治療として最近用いられる。ソマトスタチンは 各種のホルモンの分泌を抑制する作用を持ってい るが，この誘導体はより強力な作用を有し，膵内 分泌時腫瘍からの gastrin, VIPなどのホルモンの 分泌を抑制することが明らかにされている。治療 により症状の改善がもたらされるが，腫瘍縮小效 果に対しては疑問視されている.

\section{3. 前立腺がん}

前立腺がんは男性ホルモン依存型を有するがん である．手術適応のない症例に対し以前より除睪 
術、また女性ホルモンの投与などが行われていた。 しかし，除睪術は前立腺がんの患者が一般に高齢 とはいえ嫌われることが多く，また，女性ホルモ ン投与は水分貯留を来たし，心臓障害を悪化させ るなどの副作用があった。

Luteinizing hormone-releasing hormone ( $\mathrm{LH}^{-}$ RH）は下垂体を刺激し，性腺刺激ホルモンを分泌 させる.この誘導体の agonist である LH-RH ア ナログは強力な性腺刺激ホルモン分泌作用を有す るが，その投与を続けていると receptorに対す る down regulationにより，脱感作され、刺激作 用が失われて，除睪術を行ったレベルにまで血中 テストステロン值を低下させることが明らかにさ れたＺZoladexはその乳酸・グリコール酸コポリ マーで，皮下に月に 1 回植えこめばLH-RH アナ ログの放出を続けることが出来るようになった薬 物である．現在、進行性の前立腺がんに広く使用 され始めており，除殬術に匹敵する効果が認めら れている，また，最近では進行乳がんの治療に対 する有効性も注目されている。

\section{おわりに}

以上，乳がんを主体とし，膵内分泌腫湯, 前立腺 がんの内分泌療法について述べた。この様な種類 のがんはホルモン依存性を有するからこそここに 述べたような治療が可能なのである，最近，がん 研究の目を見張るような選展により多くのがん遺 伝子、その産物が明らかにされている。これらの 作用はその多くががん細胞の增殖因子であり，ま たいろいろな生理活性物質に対する受容体ではな いかと考えられている，すると，この様なものが より詳細に研究され，その作用機序が明らかにな ってくると，その作用をブロックする方法が広い 意味でのホルモン療法としてがん治療に取り入れ られてくる可能性が高い. 抗がん薬の開発，その 効果増強の試みが行き詰まっている現状において この方面の研究の進歩が大きく期待されている.

\section{参考文献}

1) Furr BJA and Jordan V C : The pharmacology and clinical uses of tamoxifen. Pharmac Ther $25: 127$ 1984.

2) Jackson IM and Lowery $C$ : Clinical uses of antioes trogens, Furr B J A ed. Bailliere Tindall, London, 1987. p 87

3) McGuire WL, et al : Current status of estrogen and progesterone receptors in breast cancer. Cancer 39 : 2934, 1977

4) 渡辺 享: ホルモン療法の実際, 高山昭三, 山口建 編, 癌とホルモン,メディカルビェー社, 東京, 1990 , p 44 .

5) Ingle $\mathrm{JN}$ : Principle of therapy in advanced breast cancer. Hematology/Oncology Clinics of North Amer ica. $3: 743,1989$.

6) Taylor SG, et al : Combination chemotherapy com pared to tamoxifen as initial therapy for stage IV breast cancer in elderly woman. Ann Int Med, 104 : 455, 1986

7) Calvalli $F$, et al : Concurrent or sequential use of cytotoxic chemotherapy and hormone treatment in advanced breast cancer : report of the Swiss group for clinical cancer research. Br. Med, J 286: $5,1983$.

8)阿部董他：進行再発乳癌に対する chemo-endocrine therapy の現状, Breast Cancer Today $4: 3,1988$.

9) Bauer $W$, et al : Structure- activity relationships of highly potent and specific octapeptide analogues of somatostatin. Blaha $\mathrm{K}$ and Malon P ed. Peptides 1982 . Walter de Gruyter \& Co., Berlin, 1983, p 583.

10) Battershill P E and Clissold S P : Octreotide, A re view of its pharmcodynamic and pharmacokinetic properties, and therapeutic potential in conditions associated with excessive peptide secretion. Drugs 38 : 658, 1989.

11）清野呇他：消化管ホルモン産生腫境に対する酢酸 オクトルオチド（SMS 201-95）の多施設臨床試験. ホルモンと臨床 36:581. 1988.

12）斎藤史郎、岩花弘之：ソマトスタチン誘導体の薬 理とその使い方，高山昭三，山口建編，癌とホルモ ンメディカルビュー社, 東京, 1990. p 142

13) Smith JA Jr : New methods of endocrine management of prostatic cancer. J Urology $137: 1,1987$.

14) Furr BJA and Woodburn JR : Luteinizing hormonereleasing hormone and its analogues : a review of biological properties and clinical uses. J Endocrinol Invest $11: 535,1988$.

15）Zoladex 共同研究グープ：前立腺癌内分泌療法, LH-RH analogue, ICI 118630 (Zoladex) と去势術あ るいはエストロゲン療法との臨床比較実験. 泌尿紀 要 $34: 1853,1988$. 